\title{
QUALITY OF RAW MATERIALS AT THE ENTERPRISES OF THE BAKERY INDUSTRY: THEORETICAL AND PRACTICAL ASPECTS
}

\author{
U. Trush, A. Zainchkovckiy \\ National University of Food Technologies
}

\begin{tabular}{l}
$\quad$ Key words: \\
Management \\
Product \\
Enterprise \\
Quality \\
Raw material \\
\hline
\end{tabular}

Article history:

Received 12.03.2018

Received in revised form

30.03.2018

Accepted 19.04.2018

Corresponding author:

U. Trush

E-mail:

Yuliya633@ukr.net
ABSTRACT
Qualitative finished products are the guarantor of the
efficiency and purposeful development of the quality
management system of products, including the derivative
tasks in the field of quality management, in particular, the
reduction of production costs and product shortages, high
quality of raw materials, innovative development, because
the improvement of product quality without the use of
qualitative raw materials and the use of modern innovation
methods of production and technologies is impossible.
It is established that the importance of the influence of the factor - the quality of raw materials - to ensure the production of bread and bakery products of high quality is of paramount importance. It is substantiated that the quality of raw materials (flour) by $70-80 \%$ determines the characteristics of the final product. The theoretical and practical aspects in the field of quality of raw materials at the enterprises of the bakery industry were considered and researched, which allowed to identify a number of issues, namely the absence of an algorithm (methodology) for conducting a comprehensive assessment of the supplier of raw materials (flour).

It is suggested to use the method of comprehensive assessment of the supplier of raw materials for the enterprises of the bakery industry, to avoid work with unreliable suppliers, eliminate the problem of poor quality raw materials on the enterprise.

It is proved that the proposed methodology will allow to choose the most reliable supplier from a plurality of potential for maintenance of strong long-term relations and work, taking into account the principle of mutually beneficial cooperation. It is recommended to divide suppliers into three groups for practical application of the proposed methodology.

The practical realization of the proposed methodology is carried out due to the calculation of the rating of the supplier of raw materials with the use of expert assessments, the definition of the overall assessment of the supplier's reliability and the establishment of the supplier's membership group. The reliability of the conducted researches is confirmed by the coefficient of consensus of expert opinions - coefficient of concordation of Kendel.

DOI: $10.24263 / 2225-2924-2018-24-2-7$ 


\title{
ЯКІСТЬ СИРОВИНИ НА ПІДПРИЕМСТВАХ ХЛІБОПЕКАРСЬКОї ГАЛУЗІ: ТЕОРЕТИЧНИЙ I ПРАКТИЧНИЙ АСПЕКТ
}

\author{
Ю.Л. Труш, А.О. Заїнчковський \\ Наиіональний університет харчових технологій
}

Якісна готова продукиія є гарантом ефективності та иільового розвитку системи управління якістю продукиії, щуо включає похідні завдання в управління якістю, зокрема зменшення витрат виробництва й браку продукції, високу якість сировини, інновачійний розвиток, адже підвищення якості продукції без використання якісної сировини й застосування сучасних інноваційних способів виробництва і технологій неможливе.

Встановлено, що важливість впливу фактора - якості сировини - для забезпечення виробництва хліба і хлібобулочних виробів високої якості відіграє першочергове значення. Обгрунтовано, що якість сировини (борошно) на 70-80\% визначає характеристики кінцевої продукції. Розглянуто та досліджено теоретичні й практичні аспекти якості сировини на підприємствах хлібопекарської галузі. Це дало змогу виявити ряд питань, що полягають у відсутності алгоритму (методики) проведення комплексної оиінки постачальника сировини (борочна).

Запропоновано використати методику комплексної оцінки постачальника сировини для підприємств хлібопекарської галузі, уникнення роботи 3 ненадійними постачальниками, усунення проблем надходження неякісної сировини на підприємство.

Доведено, що запропонована методика дасть змогу із множини потениійних постачальників вибрати найбільш надійного для підтримання міџних довгострокових зв'язків і роботи з ним з урахуванням принципу взаємовигідної співпраці. Рекомендовано для практичного застосування запропонованої методики постачальників поділити на три групи.

Проведено практичну реалізацію запропонованої методики внаслідок розрахунку бальної очінки постачальника сировини із застосуванням експертних оцінок, визначенням сумарної оцінки надійності постачальника та встановленням групи належснсті постачальника. Достовірність проведених досліджень підтверджено коефіиієнтом узгодженості думок експертів коефіцієнтом конкордації Кендела.

Ключові слова: управління, продукт, підприємство, якість, сировина.

Постановка проблеми. Необхідно відзначити, що питання підвищення якості сировини в сучасних системах управління якістю недостатньо розглянуті та в недостатньому обсязі використовуються на практиці в тісному зв'язку із застосуванням комплексної оцінки постачальника сировини на підприємствах хлібопекарської галузі. Дослідження діяльності підприємств хлібопекарської галузі показали, що основними та першочерговими шляхами покращення системи управління якістю продукції $є$ вдосконалення іiі складо- 
вих, серед яких чинне місце належить теоретичним і практичним засадам підвищення якості сировини в контексті обгрунтування алгоритму проведення комплексної оцінки іiі постачальника з метою виготовлення якісної продукції.

Аналіз останніх досліджень і публікацій. Аналіз літературних джерел показав, що на конкурентоспроможність продукції та підприємства, як основного чинника прибутковості його діяльності, впливають ціни на продукцію, післяпродажний сервіс, маркетингове оточення, якість продукції, яка передусім залежить від якості сировини, що використовується для ії виробництва.

Теоретичні та практичні суперечки, які виникали в ході вирішення питань підвищення якості сировини на підприємствах хлібопекарської галузі, і нині тривають у сучасному економічному світі.

Так, наприклад, I.В. Алєксєєв досліджував актуальні питанння удосконалення елементів систем управління якістю продукції на підприємстві, одним 3 яких є якість сировини. Е.Б. Комлєв приділив увагу покращенню якості сировини на підприємствах як основному чиннику, що гарантує високу якість готової продукції. М.І. Шаповал досліджував якість сировини на підприємствах як один із факторів, що забезпечує ефективне управління якістю готової продукції. Р.В. Бичківський відзначив теоретичну й практичну значущість якості сировини для виробництва продукції харчової промисловості та послуг.

Метою статті $є$ дослідження теоретичних і практичних аспектів управління якістю сировини на підприємствах хлібопекарської галузі, що полягає в обгрунтуванні алгоритму проведення комплексної оцінки постачальника сировини.

Викладення основних результатів дослідження. Вищезазначене обумовлює необхідність обгрунтування алгоритму (методики) проведення комплексної оцінки постачальника сировини 3 метою усунення причин виробництва неякісної продукції, оскільки цей фактор має опосередкований вплив на якість готової продукції. Дослідження питання проведемо на прикладі зразкових підприємств 3 управління якістю. Зокрема, «Виробничий цех № 2» ПАТ «Київхліб», «Виробничий цех № 10» ПАТ «Київхліб» і «Виробничий цех № 12» ПАТ «Київхліб», на яких впроваджена система управління якістю продукції. Запропонована методика дасть змогу запобігти непередбачуваним надходженням на підприємство сировини від ненадійних постачальників і визначити перспективи роботи з ними.

Важливість впливу фактора якості сировини має центральне значення для забезпечення виробництва хліба і хлібобулочних виробів високої якості, оскільки якість сировини (борошно) на 70-80\% визначає характеристики кінцевої продукції.

На досліджуваних підприємствах («Виробничий цех № 2» ПАТ «Київхліб», «Виробничий цех № 10» ПАТ «Київхліб» і «Виробничий цех № 12» ПАТ «Київхліб») рівень впливу цього чинника на дефектність продукції становить у середньому 7,7\% за 2011-2015 роки, а кількість випадків дефектів i, як наслідок, браку через невисоку якість борошна зросла втричі порівняно 3 попередніми роками і досягла $12 \%$.

Це свідчить про недостатню увагу підприємств до постачальників сировини і таких проблем, як надходження борошна 3 прихованими властивостями, 
що проявляється лише в процесі виготовлення хліба й обумовлює брак готової продукції, а також про низьку ефективність вхідного контролю сировини на підприємстві.

Для усунення існуючих проблем і їх повторного виникнення, керуючись принципом взаємовигідної співпраці з постачальниками, пропонується методика комплексної оцінки постачальника сировини для підприємств хлібопекарської галузі, що дасть змогу 3 декількох потенційних постачальників вибрати найкращого для підтримання міцних довгострокових партнерських зв'язків і співпраці [1-5].

Необхідно відзначити, що подібна оцінка постачальників в українських умовах мала місце і знаходила застосування, в основному, на підприємствах машинобудування, а на підприємствах харчової промисловості така методика, як правило, не застосовувалася. Запропонована методика розроблена 3 урахуванням накопиченого досвіду в цьому напрямку й зорієнтована на підприємство хлібопекарської галузі, що відображає його специфіку роботи та особливості географічного положення [4].

Використання комплексної оцінки постачальника дасть змогу зменшити вплив фактора якості сировини на появу дефектів продукції, а також усунути випадкові незаплановані поставки сировини від ненадійних постачальників i виникнення невчасних поставок.

Методика, яка пропонується, передбачає бальну оцінку факторів за різними показниками і в комплексі охоплює всі сторони процесу доставки та якісні характеристики сировини. Зміст показників, які розкривають вплив факторів надійності постачальника, визначено у табл. 1.

Таблиця 1. Комплексна оцінка постачальника сировини (борошно) для підприємств хлібопекарської галузі

\begin{tabular}{|c|c|c|}
\hline $\begin{array}{c}\text { Фактор, що впливає на } \\
\text { надійність постачальника }\end{array}$ & & Показники, що розкривають вплив факторів \\
\hline \multirow{4}{*}{$\begin{array}{l}\text { 1. Якісні характеристики } \\
\text { сировини, що надходить }\end{array}$} & 1.1 & $\begin{array}{c}\text { Відповідність показників якості сировини нормативним } \\
\text { документам }\end{array}$ \\
\hline & 1.2 & Стабільність вхідного рівня якості сировини \\
\hline & 1.3 & Якість сировини при переробці \\
\hline & 1.4 & Умови транспортування сировини \\
\hline \multirow{4}{*}{$\begin{array}{l}\text { 2. Місцезнаходження } \\
\text { постачальника }\end{array}$} & 2.1 & Відстань регіону поставки \\
\hline & 2.2 & Кліматичні умови в регіоні постачальника \\
\hline & 2.3 & Репутація регіону постачальника \\
\hline & 2.4 & Можливість оперативної реакції на претензії \\
\hline \multirow{4}{*}{$\begin{array}{l}\text { 3. Організація постачання } \\
\text { сировини }\end{array}$} & 3.1 & Виконання графіка поставок \\
\hline & 3.2 & Ритмічність поставок \\
\hline & 3.3 & Оперативність компенсації втрат від браку \\
\hline & 3.4 & $\begin{array}{c}\text { Повнота включення в контракт вимог замовника до } \\
\text { якості сировини } \\
\end{array}$ \\
\hline \multirow{4}{*}{$\begin{array}{l}\text { 4. Перспективність роботи } 3 \\
\text { постачальником }\end{array}$} & 4.1 & $\begin{array}{c}\text { Відповідність політики та цілей постачальника } 3 \\
\text { управління якістю цілям споживачів } \\
\end{array}$ \\
\hline & 4.2 & Можливість функціонувати в умовах конкурентної боротьби \\
\hline & 4.3 & Рівень підготовки і навчання персоналу \\
\hline & 4.4 & $\begin{array}{c}\text { Застосування комплексних підходів до управління } \\
\text { якістю сировини }\end{array}$ \\
\hline
\end{tabular}


Так, на базі накопиченого досвіду співпраці досліджуваних підприємств 3 постачальниками пропонується виділити чотири ключові чинники, що впливають на надійність постачальника сировини для підприємств хлібопекарської галузі:

1) якісні характеристики сировини, що надходить;

2) місцезнаходження постачальника;

3) організація поставок сировини;

4) перспективність роботи з постачальником.

Фактори, наведені вище, перераховані в порядку зменшення їх важливості для досліджуваних підприємств галузі. Основним фактором запропонованої методики є рівень якості сировини, що характеризується відповідністю іiі властивостей вимогам нормативно-технічної документації, умовам доставки на підприємство і стабільним рівнем ії якості.

Другим за важливістю чинником $є$ місцезнаходження постачальника, що обумовлено віддаленістю регіону, репутацією і кліматичними умовами, а також можливістю оперативної реакції на претензії. Дані показники є важливими з точки зору забезпечення безперебійності і дотримання термінів поставок сировини [3].

Не менш важливим $є$ чинник організації постачання сировини, результат оцінки якого залежить від виконання постачальником графіка поставок, забезпечення їх ритмічності, повноти виконання обсягів замовлень підприємства-замовника, що виступають у ролі споживачів, а також оперативності заміни неякісної сировини.

Крім зазначених факторів, у комплексну оцінку врахований фактор перспективності постачальника, що дає змогу планувати замовлення партій сировини в майбутньому від найнадійніших партнерів.

Методика комплексної оцінка постачальника визначається сумарною оцінкою показників по кожному фактору. Оскільки кожен фактор має різний вплив на надійність постачальника і якість сировини, в сумарній оцінці передбачено коефіцієнти, що визначають ранг кожного фактора. Ранжування впливу факторів доцільно проводити експертним шляхом із залученням працівників таких підрозділів підприємства, як відділ постачання, відділ 3 управління якістю, виробнича лабораторія, технологічна служба. На початковому етапі рекомендується встановити коефіцієнти рангу, що в сумі становлять 1:

- РФ1 - коефіцієнт фактора № $1-0,5$;

- РФ2 - коефіцієнт фактора № $2-0,2$;

- РФ3 - коефіцієнт фактора № $3-0,2$;

- РФ4 - коефіцієнт фактора № $4-0,1$.

Враховуючи вищевикладене, комплексна оцінка постачальника матиме такий вигляд:

$$
\text { Ок }=\text { РФ1 } \cdot \Phi 1+\mathrm{P} Ф 2 \cdot \Phi 2+\mathrm{P} \Phi 3 \cdot \Phi 3+\mathrm{P} \Phi 4 \cdot \Phi 4,
$$

де РФ - ранг відповідного фактора надійності; $\Phi$ - фактор надійності постачальника; Ок - комплексна оцінка постачальника.

Для оцінки кожного фактора надійності постачальника рекомендується оцінити окремі показники, що розкривають вплив цього фактора (табл. 2). На 
початковій стадії вважаємо за можливе оцінити показники експертним шляхом за допомогою працівників вищезазначених підрозділів, що відповідають за якість сировини і роботу з постачальниками, в діапазоні від 0 до 5 балів.

Надалі рекомендується більш детально вивчити вплив зазначених показників і збільшувати діапазон оцінки до 10 балів. Таким чином, кращими показниками надійності будуть характеризуватися постачальники, які отримають 20 балів, гіршими - 0 балів. Для практичного застосування запропонованої нами методики рекомендується постачальників поділити на три групи:

1) постачальники, які отримали 4- і 5-бальні оцінки за кожен показник, а в сумі мають 16-20 балів, - надійні, 3 якими можна встановлювати довгострокові взаємовигідні відносини, здійснювати пошук нових вигідних форм роботи, розробку нових перспективних планів взаємодії;

2) постачальники, показники яких оцінені на 2-3 бали (сумарна оцінка 8-12 балів) - нестійкі, але мають можливість перейти до першої категорії при поліпшенні рівня факторів, оцінених низько;

$3)$ постачальники, відзначені низькими оцінками показників (0-1 бал), а в сумі мають $0-4$ бали, — ненадійні, з якими необхідно припинити співпрацю без відновлення в найближчій перспективі.

У тих випадках, коли комплексна оцінка постачальника набуває значення від 4 до 8 балів і від 12 до 16 балів, його діяльність потребує детального вивчення і виявлення передусім рівня тих показників, які мають найбільш високий ранг для того, щоб віднести постачальника в одну з виділених нами груп.

Практична реалізація зазначеної методики і розрахунок бальної оцінки основного постачальника сировини для досліджуваних підприємств галузі ПАТ «Київмлин» із застосуванням методу експертних оцінок наведена в табл. 2 .

Таблиця 2. Комплексна оцінка постачальника основної сировини (борошно) ПАТ «Київмлин» для досліджуваних підприємств і матриця рангів

\begin{tabular}{|c|c|c|c|c|c|c|}
\hline \multirow{2}{*}{ № фактора } & \multirow{2}{*}{ № показника } & \multicolumn{3}{|c|}{ Експерти $(r)$} & \multirow{2}{*}{ Сума рангів } & \multirow{2}{*}{$\left(\sum r_{i}-a\right)^{2}$} \\
\cline { 2 - 7 } & $1 r_{1}$ & $2 r_{2}$ & $3 r_{3}$ & & 7 \\
\hline 1 & 2 & 3 & 4 & 5 & 6 & 156,25 \\
\hline \multirow{3}{*}{1} & 1.1 & 5 & 5 & 4 & 14 & 156,25 \\
\cline { 2 - 7 } & 1.2 & 4 & 5 & 4 & 13 & 156,25 \\
\cline { 2 - 7 } & 1.3 & 5 & 4 & 5 & 14 & 156,25 \\
\cline { 2 - 7 } & 1.4 & 5 & 5 & 4 & 14 & 132,25 \\
\cline { 2 - 7 } & 2.1 & 5 & 5 & 4 & 14 & 132,25 \\
\cline { 2 - 7 } & 2.2 & 4 & 4 & 5 & 13 & 182,25 \\
\cline { 2 - 7 } & 2.3 & 4 & 4 & 4 & 12 & 156,25 \\
\hline \multirow{3}{*}{3} & 2.4 & 5 & 4 & 5 & 14 & 182,25 \\
\cline { 2 - 7 } & 3.1 & 4 & 5 & 4 & 12 & 182,25 \\
\cline { 2 - 7 } & 3.2 & 5 & 5 & 4 & 15 & 182,25 \\
\cline { 2 - 7 } & 3.3 & 4 & 4 & 4 & 12 & 132,25 \\
\hline \multirow{3}{*}{4} & 3.4 & 5 & 4 & 5 & 12 & 132,25 \\
\hline
\end{tabular}




\begin{tabular}{|c|c|c|c|c|c|c|}
\hline \multicolumn{7}{|c|}{ Продовження табл. 2} \\
\hline 1 & 2 & 3 & 4 & 5 & 6 & 7 \\
\hline \multirow{2}{*}{4} & 4.3 & 4 & 4 & 4 & 12 & 182,25 \\
\hline & 4.4 & 4 & 4 & 4 & 12 & 182,25 \\
\hline \multicolumn{4}{|c|}{$\begin{array}{c}\text { Розрахунок сумарної оцінки надійності } \\
\text { постачальника }\end{array}$} & \multicolumn{3}{|c|}{$\begin{array}{l}40,5 \cdot(5+4+5+5)+ \\
+0,2 \cdot(5+4+4+5)+ \\
+0,2 \cdot(4+5+4+5)+ \\
+0,1 \cdot(4+4+4+4)\end{array}$} \\
\hline \multicolumn{4}{|c|}{ Сумарна оцінка надійності постачальника } & \multicolumn{3}{|c|}{18,3} \\
\hline \multicolumn{4}{|c|}{ Група, до якої відноситься постачальник } & \multicolumn{3}{|c|}{ Надійний постачальник } \\
\hline \multicolumn{4}{|c|}{$\begin{array}{c}\text { Висновок щодо співпраці з постачальником } \\
\text { співробітництва }\end{array}$} & \multicolumn{3}{|c|}{$\begin{array}{c}\text { Установка вигідного довгострокового } \\
\text { співробітництва }\end{array}$} \\
\hline
\end{tabular}

Джерело: складено і розраховано автором за даними ПАТ «Київмлин»; $1 r_{1}-$ «Виробничий цех № 10» ПАТ «Київхліб»; 2r - «Виробничий цех № 12» ПАТ «Київхліб»; $3 r_{3}$ — «Виробничий цех № 2» ПАТ «Київхліб».

Важливим моментом для оцінки узгодженості думок експертів $є$ використання дисперсійного коефіцієнта конкордації Кендела:

$$
W=12 S / m^{2}\left(n^{3}-n\right)
$$

У випадках, коли який-небудь експерт не може встановити рангову відмінність між декількома факторами і надає їм однакові ранги, розрахунок коефіцієнта конкордації відбувається 3 урахуванням поправочних коефіцієнтів за такою формулою:

$$
W=12 S /\left(m^{2}\left(n^{3}-n\right)-m\left(\sum T / 12\right)\right) .
$$

$\mathrm{У}$ табл. 2 спеціально приведена матриця рангів з результатами опитування експертів. Кожен з них ранжує змінні за ступенем їх впливу на фактори. У нашому випадку $n=16, m=3,\left(\Sigma r_{i}-\right.$ a) $2-$ середній ранг матриці, $a=0,5 m$ $(n+1)=25,5 ; S$ - сума середнього значення всіх рангів матриці; $S=\Sigma\left(\sum r_{i}-a\right)$ $2=25581$. У вихідних ранжованих рядах спостерігаються однакові ранги (див. дані по експертам 1, 2, 3). У зв'язку з цим виявляють поправні коефіцієнти. Їх значення наведені в табл. 3.

\section{Таблиця 3. Значення поправних коефіцієнтів}

\begin{tabular}{|c|c|c|}
\hline \multirow{2}{*}{ Експерти } & \multicolumn{2}{|c|}{ Поправні коефіцієнти } \\
\cline { 2 - 3 } & $T=t^{3}-t$ & $T / 12$ \\
\hline 1 & $\left(5^{3}-5\right)+\left(4^{3}-4\right)=180$ & 15 \\
\hline 2 & $\left(5^{3}-5\right)+\left(4^{3}-4\right)=180$ & 15 \\
\hline 3 & $\left(5^{3}-5\right)+\left(4^{3}-4\right)=180$ & 15 \\
\hline
\end{tabular}

Маючи всі необхідні дані і з огляду на поправні коефіцієнти, розрахуємо коефіцієнт конкордації Кендела за допомогою формули (3):

$$
W=12 \cdot 28581 /\left(3^{2}\left(16^{3}-16\right)-3(15+15+15)\right)=0,83,
$$

де $W=0,83$ - коефіцієнт конкордації Кендела [5].

Отже, в ході застосованої методики комплексної оцінки постачальника основної сировини ПАТ «Київмлин» можна зробити висновок, що 3 цим постачальником можна встановлювати вигідне довгострокове співробіт- 
ництво, тому що оцінка надійності постачальника дорівнює 18,3 бала та відноситься до першої групи — надійний постачальник.

Достовірність проведених досліджень підтверджено коефіцієнтом узгодженості думок експертів — коефіцієнтом конкордації Кендела, який становить 0,83 (максимальне значення даного коефіцієнта дорівнює 1, чим ближчий отриманий результат до 1 , тим більш узгоджені думки експертів).

\section{Висновки}

Запропонована методика комплексної оцінки постачальника сировини для підприємств хлібопекарської галузі дасть змогу провести якісний аналіз постачальника борошна, що заснований на комплексному обліку й оцінці всіх сторін діяльності підприємства 3 урахуванням економічних показників i важливих факторів, та забезпечить можливість обрати надійного серед існуючих, з яким можна працювати в довгостроковій перспективі.

\section{Література}

1. Алєксєєв I.В. Економічний механізм управління розвитком підприємства / І.В. Алєксєєв та інші. - Львів : Світ, 2009. - 154 с.

2. Чернелевский Л.М. Экономический анализ на предприятиях пищевой промышленности / Л. Чернелевский, А.В. Михайленко. — Москва : ИНФА-М, 2010. — 254 с.

3. Комлев Е.Б. Анализ конкурентоспособности товаров / Маркетинг в России и за рубежом. - 2009. - № 3. - С. 45-49.

4. Шаповал М.I. Менеджмент якості: підручник / М.І. Шаповал. - 3-є вид., випр. і доп. Київ : Т-во «Знання», КОО, 2007. - $471 \mathrm{c}$.

5. Бичківський Р.В. Управління якістю: навчальний посібник / Р.В. Бичківський — Львів : ДУ «Львівська політехніка», 2008. - 329 с. 